\title{
Front Matter: Volume 11672
}

, "Front Matter: Volume 11672," Proc. SPIE 11672, Laser Resonators, Microresonators, and Beam Control XXIII, 1167201 (28 April 2021); doi: $10.1117 / 12.2596694$

SPIE. Event: SPIE LASE, 2021, Online Only 


\title{
PROCEEDINGS OF SPIE
}

\section{Laser Resonators, Microresonators, and Beam Control XXIII}

\author{
Vladimir S. Ilchenko \\ Andrea M. Armani \\ Julia V. Sheldakova \\ Alexis V. Kudryashov \\ Alan H. Paxton \\ Editors
}

6-11 March 2021

Online Only, United States

Sponsored and Published by

SPIE 
The papers in this volume were part of the technical conference cited on the cover and title page. Papers were selected and subject to review by the editors and conference program committee. Some conference presentations may not be available for publication. Additional papers and presentation recordings may be available online in the SPIE Digital Library at SPIEDigitallibrary.org.

The papers reflect the work and thoughts of the authors and are published herein as submitted. The publisher is not responsible for the validity of the information or for any outcomes resulting from reliance thereon.

Please use the following format to cite material from these proceedings:

Author(s), 'Title of Paper," in Laser Resonators, Microresonators, and Beam Control XXIII, edited by Vladimir S. Ilchenko, Andrea M. Armani, Julia V. Sheldakova, Alexis V. Kudryashov, Alan H. Paxton, Proc. of SPIE 11672, Seven-digit Article CID Number (DD/MM/YYYY); (DOI URL).

ISSN: 0277-786X

ISSN: 1996-756X (electronic)

ISBN: 9781510641792

ISBN: 9781510641808 (electronic)

Published by

SPIE

P.O. Box 10, Bellingham, Washington 98227-0010 USA

Telephone +1 3606763290 (Pacific Time)

SPIE.org

Copyright @ 2021 Society of Photo-Optical Instrumentation Engineers (SPIE).

Copying of material in this book for internal or personal use, or for the internal or personal use of specific clients, beyond the fair use provisions granted by the U.S. Copyright Law is authorized by SPIE subject to payment of fees. To obtain permission to use and share articles in this volume, visit Copyright Clearance Center at copyright.com. Other copying for republication, resale, advertising or promotion, or any form of systematic or multiple reproduction of any material in this book is prohibited except with permission in writing from the publisher.

Printed in the United States of America by Curran Associates, Inc., under license from SPIE.

Publication of record for individual papers is online in the SPIE Digital Library.

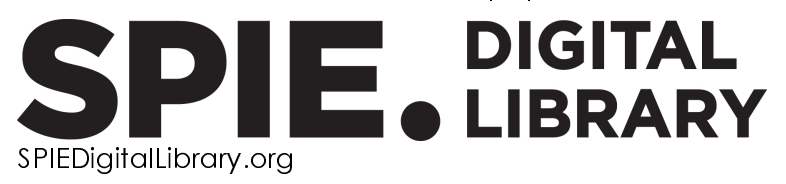

Paper Numbering: A unique citation identifier (CID) number is assigned to each article in the Proceedings of SPIE at the time of publication. Utilization of CIDs allows articles to be fully citable as soon as they are published online, and connects the same identifier to all online and print versions of the publication. SPIE uses a seven-digit CID article numbering system structured as follows:

- The first five digits correspond to the SPIE volume number.

- The last two digits indicate publication order within the volume using a Base 36 numbering system employing both numerals and letters. These two-number sets start with 00, 01, 02, 03, 04, 05, 06, 07, 08, 09, OA, OB ... 0Z, followed by 10-1Z, 20-2Z, etc. The CID Number appears on each page of the manuscript. 


\section{Contents}

OPTICAL FREQUENCY COMBS I

$1167205 \quad$ Inverse spectral design of Kerr microcomb pulses [11672-2]

$1167206 \quad$ Frequency comb generation in silicon nitride resonators with amplitude modulated pump [1 1672-3]

$1167207 \quad$ Applications of ultra-silicon-rich nitride devices for nonlinear integrated photonics (Invited Paper) [1 1672-4]

\section{OPTICAL FREQUENCY COMBS II}

$1167209 \quad$ Fabrication of dispersion engineered ultrahigh-Q crystalline optical microresonator for broadbandwidth optical parametric oscillation (Invited Paper) [1 1672-6]

11672 OA On parametric generation of deep UV light in monolithic cavities with cubic nonlinearity [11672-7]

11672 OC In search of time crystalline behavior in Kerr optical frequency combs (Invited Paper) [1 1672-9]

\section{OPTICAL FREQUENCY COMBS III}

$116720 \mathrm{O}$ Optimization of the self-injection locking and resonator characterisation in this regime [1 1672-13]

NOVEL TOPOLOGIES AND DEVICES

11672 OK Anti-Stokes and cascaded Stokes Raman microlaser from an organically modified optical resonator [11672-17]

11672 ON Dynamical analysis of miniature optoelectronic oscillators based on whispering-gallery mode modulators with quadratic nonlinearity (Invited Paper) [1 1672-20]

\section{MICRORESONATOR SENSORS}

$1167200 \quad$ Micro-optical-electro-mechanical systems (MOEMS) sensors based on cavity optomechanics (Invited Paper) [1 1672-21] 
$116720 Q \quad$ Microresonator sensors based on evanescent field perturbation [1 1672-25]

11672 OR Progress on optical microspheres for $\mathrm{CO}_{2}$ sensors [1 1672-27]

11672 OS Optical micro-resonator sensor for air velocity measurement [1 1672-29]

11672 OT Stimulated chiral light-matter interactions in biological microlasers [1 1672-40]

\section{BEAM SHAPING I}

11672 OU Fibre-delivered kilowatt petal beams with self-healing properties [1 1672-22]

11672 OV 240-mm bimorph deformable mirror for wavefront correction at the PEARL facility (Invited Paper) [1 1672-24]

11672 OW Focusing laser beam through pinhole using high-resolution stacked-actuator deformable mirror [11672-26]

BEAM SHAPING II

1167210 Application-based m-square measurement techniques for industrial lasers [1 1672-32]

$1167211 \quad$ Revised theory for the linewidth of diode lasers under external optical feedback [1 1672-33]

\section{POSTER SESSION}

$1167212 \quad$ Non-paraxial diffractive optical elements for beam-splitting with ultra-high uniformity [1 1672-34]

$1167213 \quad$ Frequency comb generation in whispering gallery mode silica microsphere resonators [1 1672-35]

$1167214 \quad$ Bimorph vs stacked actuator deformable mirror for laser beam focusing through a moderately scattering medium [1 $1672-36]$

1167215 Small-aperture stacked-array deformable mirror made of the piezoceramic combs [1 1672-37]

1167216 Computer modelling of WGM microresonators with a zinc oxide nanolayer using COMSOL multiphysics software [1 1672-38]

$1167217 \quad$ Mode family analysis for PMMA WGM micro resonators using spot intensity changes [1 1672-39] 